\title{
Reproductive cycle of Anomalocardia brasiliana (Mollusca: Bivalvia: Veneridae) in the estuary of the Cachoeira River, Ilhéus, Bahia
}

\author{
Luz, JR.* and Boehs, G.*

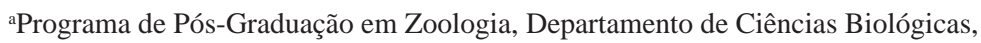 \\ Universidade Estadual de Santa Cruz - UESC, Rod. Ilhéus-Itabuna, Km 16, CEP 45650-900, Ilhéus, BA, Brazil \\ *e-mail: joaldoluz@yahoo.com.br; gboehs@uesc.br
}

Received April 4, 2010 - Accepted August 19, 2010 - Distributed 31 August, 2011

(With 13 figures)

\begin{abstract}
The aim of this study was to characterize the reproductive cycle of Anomalocardia brasiliana, typical of the estuarine region of the Cachoeira River, Ilhéus, Bahia, Brazil. For this purpose, 20 specimens were collected biweekly between August 2005 and August 2006 on an intertidal bank (14 48' 23' S and 39 02' 47” W). The animals were measured on the anteroposterior axis (length), examined macroscopically and removed from the shell and fixed in Davidson's solution. Subsequently, the tissues were impregnated in paraffin, cut into $7 \mu \mathrm{m}$ sections and stained with Harris hematoxylin and eosin (HE). The slides were examined under a light microscope. The water temperature at the site ranged from 24 to $30.5^{\circ} \mathrm{C}$ (mean: $27.4{ }^{\circ} \mathrm{C}$; $\mathrm{SD} \pm 1.9$ ), salinity from zero to 23 (mean: 13.7; $\mathrm{SD} \pm 7.5$ ) and rainfall from $28.3 \mathrm{~mm}$ to $248.8 \mathrm{~mm}$ monthly (yearly mean: $130 \mathrm{~mm})$. The sample $(\mathrm{n}=478)$ showed a sex ratio $(\mathrm{M}: \mathrm{F})$ of $1: 1.2$ $(\mathrm{p}<0.05)$ and no cases of hermaphroditism. There was no sexual dimorphism. Males and females showed reproductive synchrony. The reproductive cycle was continuous, with releases of gametes mainly in spring, summer and autumn. These results are similar to those found in other regions, but there was no reproductive rest period as reported for populations in higher latitudes.
\end{abstract}

Keywords: Bivalves, gametogenic cycle, reproductive stages, sex ratio, Bahia.

\section{Ciclo reprodutivo de Anomalocardia brasiliana (Mollusca: Bivalvia: Veneridae) no estuário do Rio Cachoeira, Ilhéus, Bahia}

\begin{abstract}
Resumo
Neste estudo objetivou-se caracterizar o ciclo reprodutivo de Anomalocardia brasiliana da região estuarina do rio Cachoeira, Ilhéus, Bahia, Brasil. Para tal, 20 espécimes foram coletados quinzenalmente, entre agosto de 2005 e

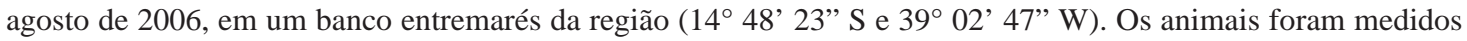
quanto ao seu eixo ântero-posterior (comprimento), analisados macroscopicamente, retirados da concha e fixados em solução de Davidson. O processamento posterior dos tecidos incluiu impregnação em parafina, obtenção de cortes com $7 \mu \mathrm{m}$ de espessura e coloração com Hematoxilina de Harris e Eosina (HE). As lâminas foram examinadas em microscopia de luz. A temperatura da água do local variou de 24 a $30,5^{\circ} \mathrm{C}$ (média: $27,4{ }^{\circ} \mathrm{C}$; $\mathrm{DP} \pm 1,9$ ), a salinidade de zero a 23 (média: 13,7; DP $\pm 7,5$ ) e a precipitação pluviométrica mensal de $28,3 \mathrm{~mm}$ a $248,8 \mathrm{~mm}$ (valor médio anual: $130 \mathrm{~mm})$. A população analisada $(\mathrm{n}=478)$ apresentou proporção sexual $(\mathrm{M}: \mathrm{F})$ de $1: 1,2(\mathrm{p}<0,05)$ e nenhum caso de hermafroditismo. Não houve dimorfismo sexual. Machos e fêmeas apresentaram sincronismo reprodutivo e o ciclo de reprodução foi contínuo, com pequenos picos de liberação de gametas principalmente na primavera, no verão e no outono. Esses resultados foram similares aos encontrados em outras regiões, porém não houve um período de repouso sexual propriamente dito, como está relatado em populações de latitudes mais altas.
\end{abstract}

Palavras-chave: Bivalves, ciclo gametogênico, estádios reprodutivos, razão sexual, Bahia. 


\section{Introduction}

Studies on the reproduction of mollusks allow us to understand aspects of the biology and ecology of these organisms and therefore assist in the management of natural and cultured populations, as well as in the conservation of the species.

The mollusks of the family Veneridae include several species of economic interest. The reproduction of these bivalves has been studied in various places along American coasts by Loosanoff (1937) in Long Island Sound (USA); Ansell (1961) in Kames Bay, Millport (USA); Narchi (1976) in São Paulo State (Brazil); Pizarro and Cruz (1987) in Sardial, Guanacaste (Costa Rica); Grotta and Lunetta (1980) in Paraíba State (Brazil); Grotta and Lunetta (1982) in Paraíba and São Paulo (Brazil); Borzone (1992) in San José Gulf (Argentina); García-Domínguez et al. (1993) in Baja California (Mexico); García-Domínguez et al. (1994) on the Island of Espiritu Santo (Mexico); Boehs (2000) in Paraná State (Brazil); Araújo (2001) in Santa Catarina State (Brazil); Borzone et al. (2001) in southern Brazil; and Rocha-Barreira and Araújo (2005) in Ceará State (Brazil).

The venerid Anomalocardia brasiliana (Gmelin, 1791), the Carib pointed-venus, inhabits intertidal banks and shallow subtidal areas protected from wave action and currents (Narchi, 1974). It is a euryhaline species (Leonel et al., 1983). Its occurrence was recorded by Rios (2009) in the West Indies, Suriname, Brazil and Uruguay. Because it is well accepted for human consumption and is easy to locate and capture, it is exploited in several places along the Brazilian coast, for both subsistence consumption and sales to the consumer market (Pezzuto and Echternacht, 1999). In Brazil, it is known as: "berbigão", "vôngole", "mija-mija", "sarnambi”, "sernambi pequeno", "samanguaiá”, "chumbinho", "papa-fumo", "sarro-depito", "marisco-pedra", and "maçunim" (Narchi, 1972; Denadai et al., 2006; Farias and Rocha-Barreira, 2007; Rios, 2009). Although it is consumed and marketed along the entire coast of the state of Bahia (a distance of approximately $1,100 \mathrm{~km}$ ), there are no studies on the reproductive aspects of $A$. brasiliana. The aim of this study was to characterize the reproductive cycle of the species in the estuary of the Cachoeira River, Ilhéus on the southern coast of Bahia.

\section{Material and Methods}

Samples of 20 specimens of A. brasiliana were taken every two weeks between August 2005 and August 2006 on a bank (shoal) located in the sandy/muddy estuary region of the Cachoeira River at coordinates $14^{\circ} 48^{\prime} 23^{\prime \prime} \mathrm{S}-$ $39^{\circ} 02^{\prime} 47^{\prime}$ 'W. Because they are buried near the sediment surface, the animals were obtained by manual collection during low tide. Water temperature and salinity were measured at each collection, using a standard mercury thermometer and an Atago S/Mill hand refractometer, respectively. Rainfall data from this period were obtained from the Executive Commission Plan of Cocoa Farming - CEPLAC, in Ilhéus.

The laboratory processing of animals included: length measurements (anterior-posterior axis, in $\mathrm{mm}$ ), macroscopic analysis for possible evidence of sexual dimorphism or signs of parasitism, removal of the shell, and fixation in Davidson's solution (Shaw and Battle, 1957). After a period of 24 to 30 hours, the specimens were transferred to $70 \%$ ethanol and then subjected to routine histology, including: impregnation in paraffin, cutting of sections $7 \mu \mathrm{m}$ thick using a microtome, staining with Harris hematoxylin and eosin (HE) and mounting of slides. A total of 478 individuals were analyzed. The material was examined under a light microscope to record the sex and stage of the reproductive cycle, based on classifications proposed by Araújo (2001), Carpes-Paternoster (2003) and Rocha-Barreira and Araújo (2005). The Chi-square $\left(\chi^{2}\right)$ test was used to assess significant differences in sex ratio. The Kruskal-Wallis test was used to indicate possible differences in the release of gametes during the study period (significance limit: $\alpha=0.05$ ). Spearman's coefficient was used to establish possible correlations between the release of gametes and temperature, salinity and rainfall. All the statistical analyses were performed using BioEstat 5.0 software.

\section{Results}

The mean water temperature was $27.4{ }^{\circ} \mathrm{C}(\mathrm{SD} \pm 1.9$; $\mathrm{N}=25)$. The highest temperature $\left(30.5^{\circ} \mathrm{C}\right)$ occurred in April and the lowest $\left(24^{\circ} \mathrm{C}\right)$ in May and July 2006 (Figure 1). The mean salinity was $13.7(\mathrm{SD} \pm 7.5 ; \mathrm{N}=25)$. The lowest value (zero) was recorded in the collections from August and December 2005 and from April to June 2006; the highest salinity (23) occurred in March 2006 (Figure 2). The mean monthly rainfall was $130 \mathrm{~mm}$, with the lowest means in February $(28.3 \mathrm{~mm}$ ) and May 2006 (40.6 mm), and the highest in December 2005 (248.8 mm) and June 2006 (228.8 mm) (Figure 3). The low salinities in December 2005 and June 2006 coincided with the rainiest months of the study period.

Specimens of $A$. brasiliana had lengths between 22.1 and $39.8 \mathrm{~mm}$ (mean $32 \mathrm{~mm} ; \mathrm{SD} \pm 2.9 ; \mathrm{n}=478$ ), the range in which all organisms are considered adults, i.e., able to reproduce. No sexual dimorphism was observed. The percentage of males (M) was $41.8 \%$, and of females $(\mathrm{F})$ $51.6 \%$, resulting in a sex ratio $(\mathrm{M}: \mathrm{F})$ of $1: 1.2(\mathrm{p}<0.05)$. This difference was most significant in September 2005 and July 2006. In the collection of March 2006, the sex ratio was reversed, i.e., there was a higher proportion of males (Table 1). It was not possible to identify the sex in 31 animals $(6.5 \%)$. From these animals, three had undifferentiated gonads, while sexing was not possible in the 28 remaining ones due to parasitic castration by a digenean trematode.

Anomalocardia brasiliana showed continuous reproduction, with no rest period. The reproductive phases in males and females were synchronized. For males, there were two main peaks of total and partial 


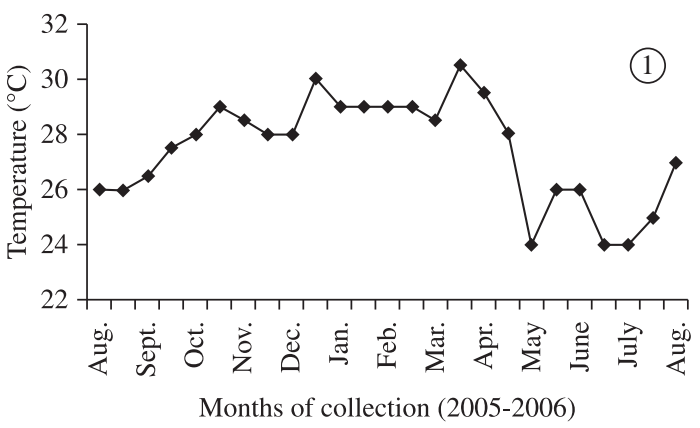

(1)


Figures 1-3. Fortnightly Values of temperature $\left({ }^{\circ} \mathrm{C}\right)$ and water salinity, and monthly rainfall mean values from the collection area of the bivalve Anomalocardia brasiliana in the estuary region of Cachoeira River (Ilhéus, Bahia), from August 2005 to August 2006.

Table 1. Absolute frequency of males (M), females (F), individuals of undetermined sex (U) and parasitic castration (C) in samples of Anomalocardia brasiliana collected in the estuary region of the Cachoeira River (Ilhéus, Bahia) between August 2005 and August 2006, and results of Chi-square $\left(\chi^{2}\right)$ where $*=\alpha<0.05$.

\begin{tabular}{|c|c|c|c|c|c|c|c|}
\hline Month & $\mathbf{M}$ & $\mathbf{F}$ & $\chi^{2}$ & $\mathbf{U}$ & & $\mathbf{C}$ & Total \\
\hline Aug. & 9 & 11 & 0.20 & 0 & 0 & & 20 \\
\hline Aug. & 13 & 6 & 2.579 & 0 & & 1 & 20 \\
\hline Sept. & 9 & 10 & 0.053 & 0 & & 1 & 20 \\
\hline Sept. & 5 & 15 & $5^{*}$ & 0 & & 0 & 20 \\
\hline Oct. & 10 & 10 & 0 & 0 & & 0 & 20 \\
\hline Oct. & 9 & 10 & 0.053 & 0 & & 1 & 20 \\
\hline Nov. & 7 & 12 & 1.316 & 0 & & 1 & 20 \\
\hline Nov. & 6 & 13 & 2.579 & 0 & & 1 & 20 \\
\hline Dec. & 6 & 12 & 2 & 0 & & 2 & 20 \\
\hline Dec. & 9 & 10 & 0.053 & 0 & & 0 & 19 \\
\hline Jan. & 6 & 14 & 3.20 & 0 & & 0 & 20 \\
\hline Jan. & 7 & 11 & 0.889 & 0 & & 2 & 20 \\
\hline Feb. & 9 & 10 & 0.053 & 0 & & 1 & 20 \\
\hline Mar. & 10 & 7 & 0.529 & 0 & & 3 & 20 \\
\hline Mar. & 13 & 4 & $4.765^{*}$ & 0 & & 3 & 20 \\
\hline Apr. & 11 & 8 & 0.474 & 0 & & 1 & 20 \\
\hline Apr. & 7 & 10 & 0.529 & 1 & & 2 & 20 \\
\hline May & 6 & 10 & 1 & 2 & & 2 & 20 \\
\hline May & 10 & 10 & 0 & 0 & & 0 & 20 \\
\hline June & 10 & 10 & 0 & 0 & & 0 & 20 \\
\hline June & 7 & 11 & 0.889 & 0 & & 1 & 19 \\
\hline July & 4 & 12 & $8.236^{*}$ & 0 & & 4 & 20 \\
\hline July & 7 & 13 & 1.80 & 0 & & 0 & 20 \\
\hline Aug. & 10 & 8 & 0.222 & 0 & & 2 & 20 \\
\hline Total & 200 & 247 & $4.942 *$ & 3 & & 28 & 478 \\
\hline
\end{tabular}


release of gametes: in spring (September to November) and in midsummer through autumn (second half of January until late May). The most intense peak occurred during the autumn (Figure 4). Unlike the males, which did have a total release in some periods, the females showed complete and/or partial release with proliferation throughout the year. The main release periods in females occurred from August 2005, extending to spring, summer, autumn, and early winter of the following year, with a total elimination peak occurring (as in males) in autumn 2006 (Figure 5). In

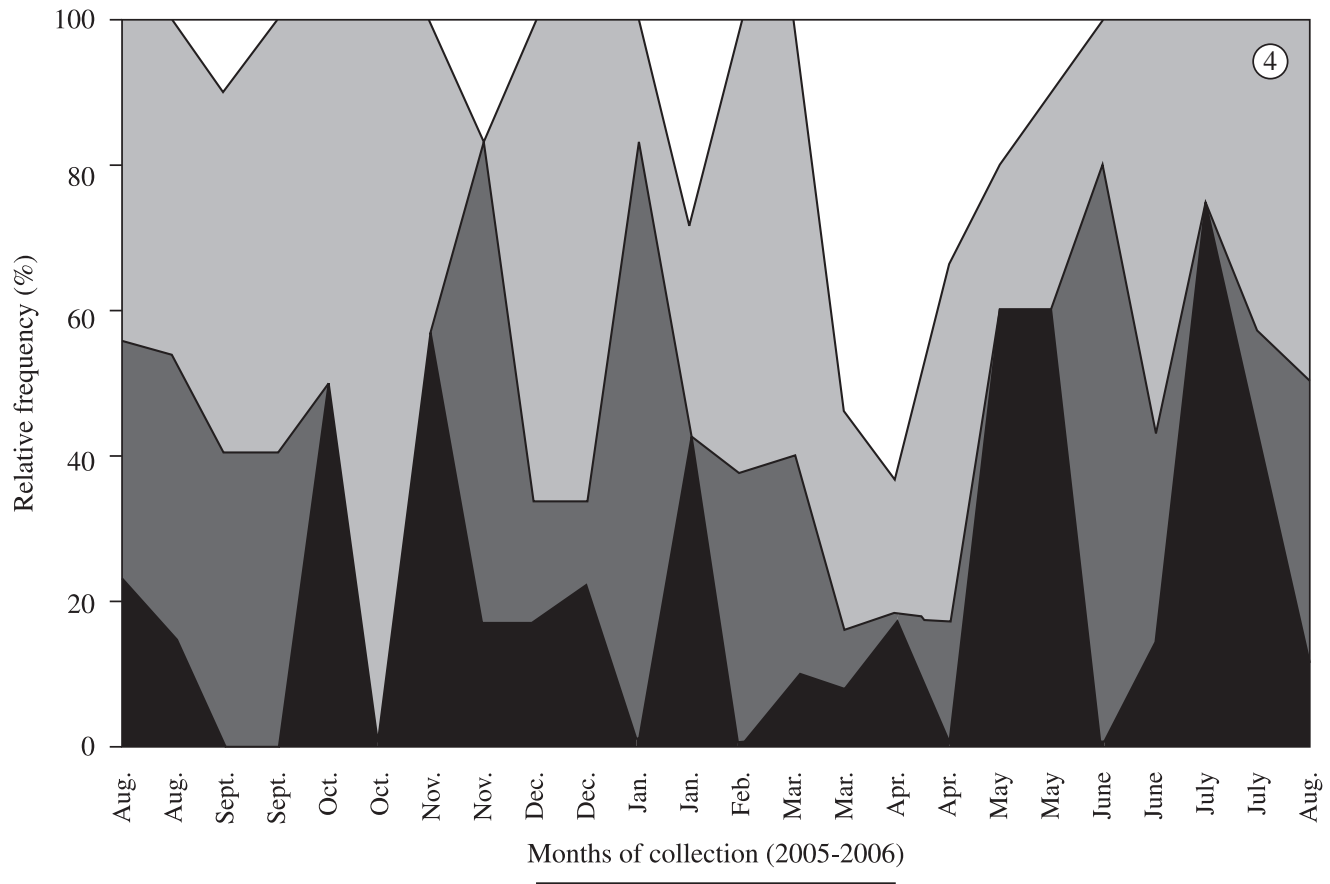

$\square \mathrm{TR} \quad \square \mathrm{PRP} \quad \square \mathrm{R} \quad \square \mathrm{G}$

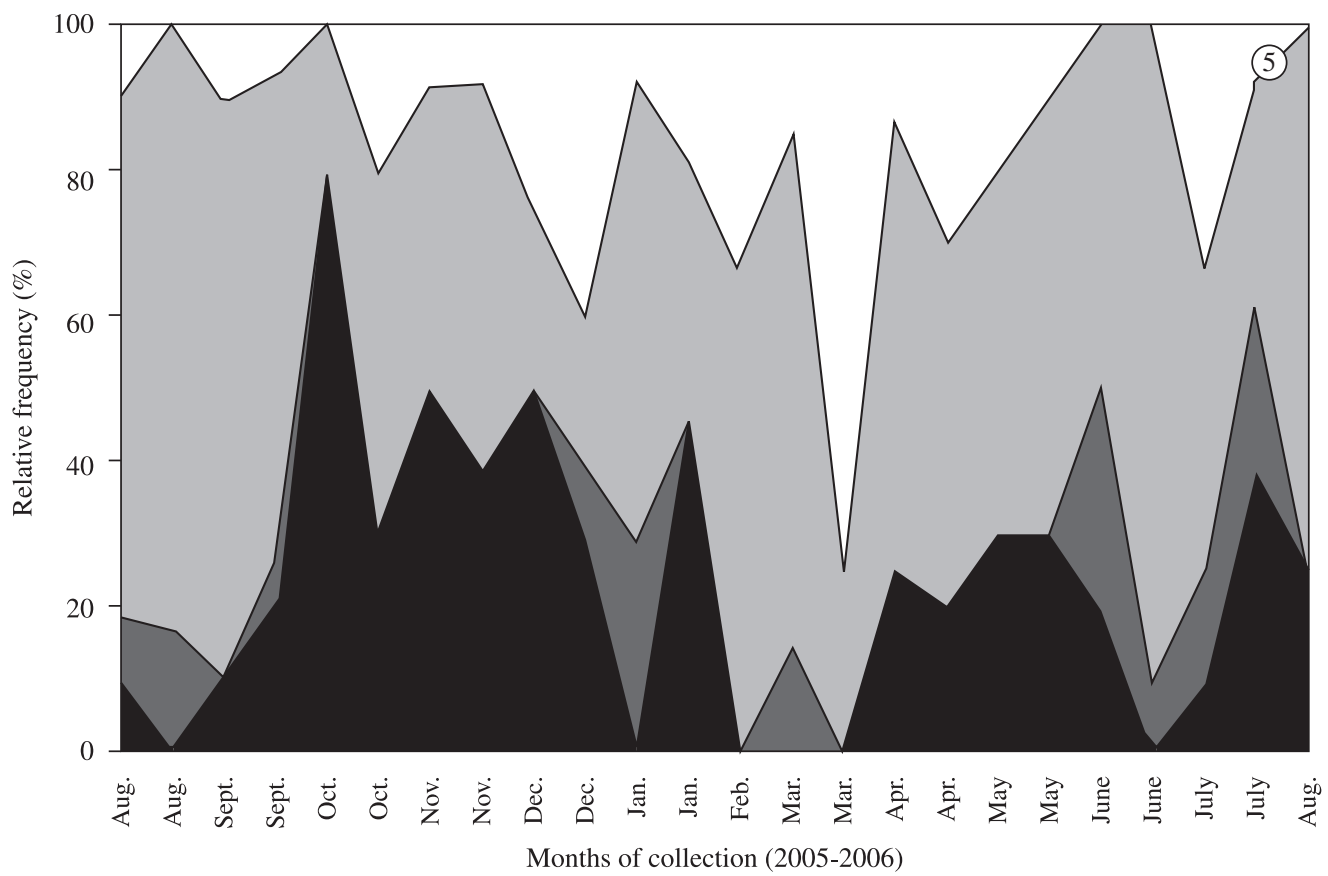

Months of collection (2005-2006)

\section{$\square \mathrm{TR} \square \mathrm{PRP} \square \mathrm{R} \quad \mathrm{G}$}

Figures 4-5. Frequency on a biweekly basis of reproductive stages in males (4) and females (5) of Anomalocardia brasiliana collected in the estuary of Cachoeira River (Ilhéus, Bahia) between August 2005 and August 2006. (G) Gametogenesis; (R) Repletion of Gametes; (PRP) Partial Release with Proliferation; Total Release (TR). (4) n = 200 and (5) n = 247. 
spite of the presence of peaks of greater release of gametes, the Kruskal-Wallis test showed that these periods did not differ significantly from the release rates occurring in the other months in males ( $\mathrm{p}=0.481)$ as well as females $(p=0.5359)$. Otherwise, the Spearman's test indicated,
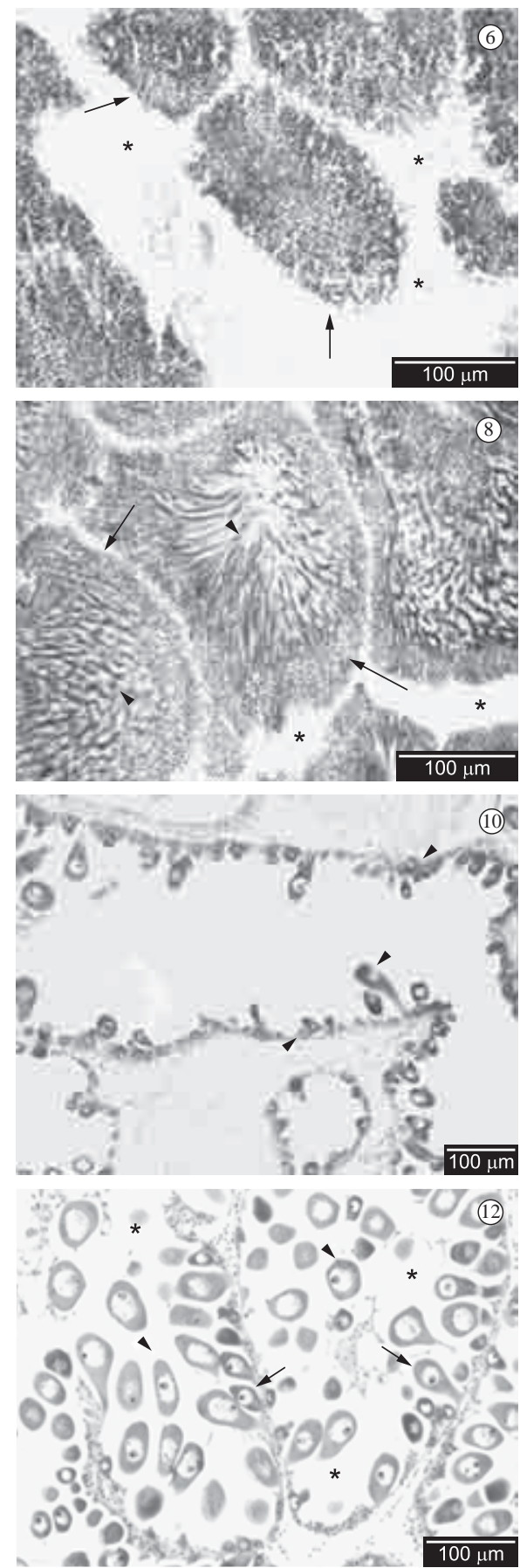

in males as well as females, a non-significant correlation ( $p>0.1$ ) between the release of gametes and the factors of temperature, salinity, and precipitation in the locale. The reproductive stages of males and females are illustrated in Figures 6-13.
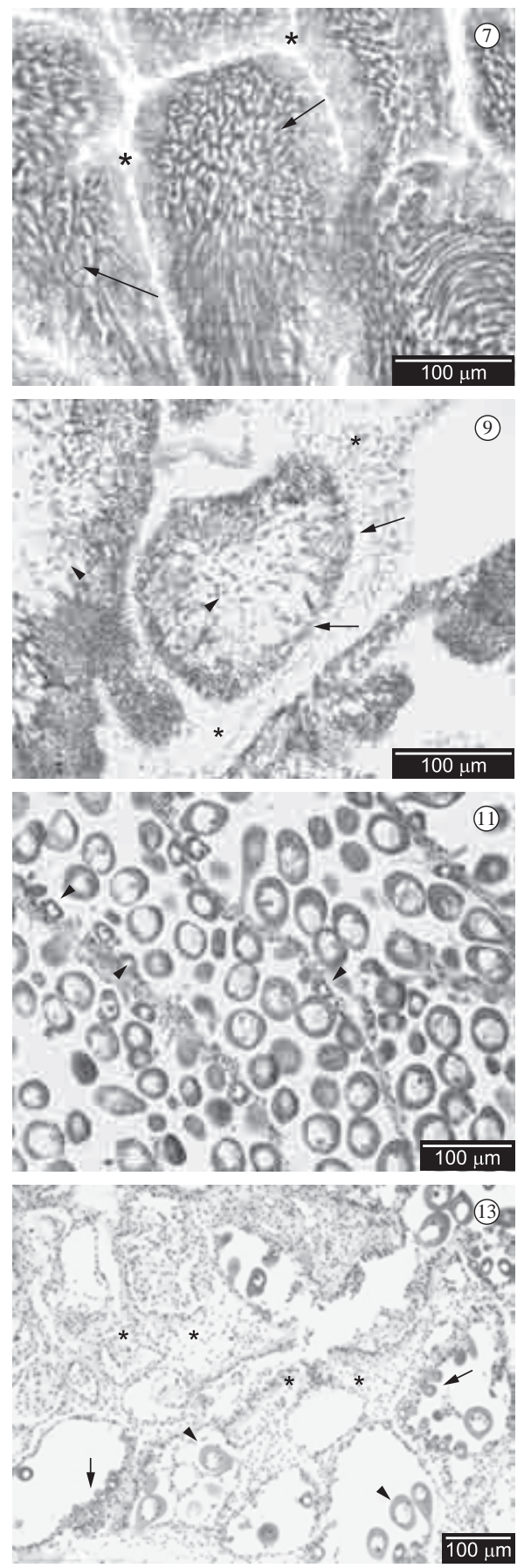

Figures 6-13. Photomicrographs of Anomalocardia brasiliana gonads in the estuary region of Cachoeira River (Ilhéus, Bahia). Male at stages of: Gametogenesis (6), Repletion of Gametes (7), Partial Release with Proliferation (8) and Total Release (9). Gonads showing follicles (arrows) with spermatogenic lineage cells under development and interfolicular space (*). Females at Gametogenesis stages (10), Repletion of Gametes (11), Partial Release with Proliferation (12) and Total Release (13). Gonads showing follicles with oocytes at different maturation levels (arrows) and spaces left by the oocytes released (*). Bar: $100 \mu \mathrm{m}$. Staining: HE. 


\section{Discussion}

As reported for the majority of bivalve mollusks (Coe, 1943; Sastry, 1979; Morton, 1991; Heller, 1993), A. brasiliana is dioecious and has no sexual dimorphism. The absence of hermaphroditism in this population agreed with observations for this species in other parts of the coast (Narchi, 1976; Grotta and Lunetta, 1980; Boehs, 2000; Araújo, 2001; Rocha-Barreira and Araújo, 2005). For the dioecious bivalves Tagelus plebeius (Lightfoot, 1786) (Psammobiidae) and Iphigenia brasiliana (Lamarck, 1818) (Donacidae) in the same region (Rio Cachoeira), Ceuta et al. (2010) observed hermaphroditism rates of $0.4 \%$ and $0.2 \%$ respectively, in the same period as this study. The authors considered the great variation in salinity and perhaps the effects of pollution at the site as possible causes for this. In agreement with Heller (1993), the causes that actually determine occasional hermaphroditism in bivalve mollusks are not yet well known. The same is true with respect to differences in the sex ratio. According to Coe (1943), males and females in similar proportions are the usual situation in marine bivalves. Morton (1991) considered that differences in the sex ratio may occur due to two main aspects: age of the organisms (since some sexual changes occur in some bivalves throughout the life cycle) and probably genetic differences between populations of the same species. In the case of A. brasiliana in the Cachoeira River estuary, the presence of a slightly higher proportion of females is similar to observations for this species in Santa Catarina (Araújo, 2001). Studies on other parts of the Brazilian coast such as in Ceará (Rocha-Barreira and Araújo, 2005), Paraiba (Grotta and Lunetta, 1980), São Paulo (Narchi, 1976), and Paraná (Boehs, 2000) showed a predominance of males. Factors such as greater longevity (Araújo, 2001) and greater resistance to adverse environmental conditions (Coe, 1936) were considered to favor the predominance of females in populations of bivalves. On the other hand, Boehs (2000) observed a sharp drop in the number of females in the post-spawning period of a population of A. brasiliana in Paraná; she attributed this to a possible mortality related to the spawning event.

With respect to the dynamics of the reproductive cycle in marine bivalves, several studies have shown that environmental conditions determine the maturation of the gonads and the process of release of gametes (Galtsoff, 1964; Andrews, 1979; Sastry, 1979; Grotta and Lunetta, 1980; Lubet, 1996). Among the abiotic factors that most affect the reproductive cycle of these organisms are temperature (Nascimento and Lunetta, 1978; Andrews, 1979; Grotta and Lunetta, 1982; Lunetta and Grotta, 1982) and salinity (Leonel et al., 1983; Couto, 1988). Temperature is directly associated with the transfer of reserves stored in the digestive gland to the developing gonads and gametes, whereas this conversion is inhibited by low temperatures (Loosanoff and Davis, 1952). This was observed in Chione pubera (Bory Saint-Vincent) in southern Brazil, where the release of gametes was related to the increase in water temperature, and gonadal reversal coinciding with lower temperatures (Borzone et al., 2001). Temperature exerts an indirect influence on the gametogenic cycle of bivalves, because it determines the qualitative and quantitative composition of plankton and therefore the food supply (Lubet, 1959).

The more or less constant high temperatures during the year in the studied region apparently favor the continuous reproductive cycles of marine bivalves. This was observed for A. brasiliana to the extent that only in late winter there was a decrease in gamete release, although this did not represent a reproductive rest period. Continuous reproduction with small reproductive peaks was also observed in A. brasiliana from other regions in northeast Brazil (Grotta and Lunetta, 1980; Rocha-Barreira and Araújo, 2005). The incidence of reproductive peaks is very evident in southeast (Narchi, 1976) and southern (Boehs et al., 2008) Brazil, especially in spring and autumn. Although the reproduction of the species in these locations is still continuous, the winter period is characterized by low emission of gametes. As reported by Boehs (2000), who studied the reproduction of $A$. brasiliana on the coast of Paraná, there seems to be a reproductive rest in that region, since it has always been possible to find a mature population, even in the months between major peaks. Comparing his data from Santa Catarina with those obtained by Narchi (1976) in São Paulo, Araújo (2001) noted a similarity mainly in autumn and spring. However, a reproductive rest period was evident in winter (June) and spring (August-October). In addition, Narchi (1976) recorded gametogenesis and elimination of gametes in this period. Winter and early spring in Santa Catarina state were also characterized by the lysing of residual female gametes and by the presence of phagocytes in the male follicles (Araújo, 2001). Comparing two geographically separated populations, one from the coast of São Paulo (tropical transition) and the other from Paraíba (tropical), Grotta and Lunetta (1982) concluded that there was variation in the duration of the reproductive period. The population in São Paulo had continuous reproduction with evident peaks, whereas the one in Paraiba was characterized by continuous reproduction without major peaks. These results agree with conclusions by Boehs (2000) and other authors (Feder et al., 1979; 1Borzone, 1992; Martínez-Córdova, 1988; Garcia-Domingues et al., 1993): Reproduction in marine bivalves tends to be continuous with small peaks in tropical regions, whereas a reduction in the spawning period occurs at higher latitudes, where temperatures rise in only a few months of the year. With respect to salinity and rainfall, Couto (1988) found a relationship between events of the reproductive cycle and salinity for the bivalve Iphigenia brasiliana in other locations in northeast Brazil. In this study, there was no clear evidence of a correlation between the reproductive cycle of $A$. brasiliana and these factors.

The existence of reproductive synchrony between males and females in the population studied here, has been previously observed by Rocha-Barreira and Araújo (2005) in Ceará. It was observed in this study that females had a 
high total release of gametes (observed by nearly empty gonads), while the total elimination was less prevalent in males than the partial elimination with proliferation. According to Grotta and Lunetta (1980), spermatogenesis in bivalves is a more rapid process than oogenesis, since more reserves must be mobilized to synthesize yolk for oocytes, requiring more time during the maturation of females.

Acknowledgments - The authors are thankful to Thiago R. Pinto and to Liliane O. Ceuta for the assistance in preparing the animals. We would also like to thank Aimê R. M. Magalhães, Sylvia M. M. Susini Ribeiro, Luís Gustavo T. Braga and Gecely R. A. Rocha for their suggestions. Finally, we would like to thank $\mathrm{CNPq}$ for the financial support awarding scholarship and CAPES for the financial aid for the project.

\section{References}

ANDREWS, JD., 1979. Pelecypoda: Ostreidae. In GIESE, AC. and PEARSE, JS. (Eds). Reproduction of marine invertebrates. New York: Academic Press. p. 293-341. vol. 5, Molluscs: Pelecypods and lesser classes.

ANSELL, AD., 1961. Reproduction, growth and mortality of Venus striatula (Da Costa) in Kames Bay, Millport. Journal of the Marine Biological Association of the United Kingdom, vol. 41, p. 191-215. http://dx.doi.org/10.1017/S0025315400001648

ARAÚJO, CM., 2001. Biologia Reprodutiva do berbigão Anomalocardia brasiliana (Gmelin, 1791) (Mollusca, Bivalvia, Veneridae) na Reserva Extrativista Marinha de Pirajubaé. São Paulo: Instituto de Biociências da Universidade de São Paulo. 204 p. Tese de Doutorado em Aquicultura.

BOEHS, G., 2000. Ecologia populacional, reprodução e contribuição em biomassa de Anomalocardia brasiliana (Gmelin, 1791) (Bivalvia: Veneridae) na Baía de Paranaguá, Paraná, Brasil. Curitiba: Universidade Federal do Paraná. 200 p. Tese de Doutorado em Zoologia.

BOEHS, G., ABSHER, TM. and CRUZ-KALED, AC., 2008. Ecologia populacional de Anomalocardia brasiliana (Gmelin, 1791) (Bivalvia, Veneridae) na Baía de Paranaguá, Paraná, Brasil. Boletim do Instituto de Pesca, vol. 34, no. 2, p. 259-270.

BORZONE, CA., 1992. El ciclo gonadal de Venus antiqua King \& Broderip 1835 (Veneridae: Bivalvia) en el Golfo San Jose. Physis, vol. 47, no. 113, p. 61-72.

BORZONE, CA., VARGAS, KM., PEZZUTO, PR. and TAVARES, YGA., 2001. Aspectos da reprodução e dinâmica populacional de Chione pubera (Bory Saint-Vicent) (Bivalvia, Veneridae) no sul do Brasil. Revista Brasileira de Zoologia, vol. 18, no. 2, p. 333-349.

CARPES-PATERNOSTER, S., 2003. Ciclo reprodutivo do mariscodo-mangue Mytella guyanensis (Lamarck, 1819) no manguezal do Rio Tavares - Ilha de Santa Catarina/SC. Florianópolis: Universidade Federal de Santa Catarina. 30 p. Dissertação de Mestrado em Aquicultura.

CEUTA, LO., BOEHS, G. and SANTOS, JJB., 2010. Hermaphroditism among dioecious Tagelus plebeius (Mollusca, Psammobiidae) and Iphigenia brasiliana (Mollusca, Donacidae) on the Cachoeira River Estuary, Ilhéus, Bahia, Brazil. Brazilian Journal of Biology, vol. 70, no. 1, p. 125-127. http://dx.doi. org/10.1590/S1519-69842010000100017

COE, WR., 1936. Sex ratios and sex changes in mollusk. Memoires du Musee Royal d'Histoire Naturelle Belgique, vol. 3, p. 69-76.
-, 1943. Sexual differentiation in mollusks I. Pelecypods. The Quarterly Review of Biology, vol. 18, p. 154-164. http://dx.doi. org/10.1086/394673

COUTO, LMMR., 1988. Ciclo reprodutivo e influência da salinidade sobre a gametogênese de Iphigenia brasiliana (Lamarck, 1818) (Mollusca: Bivalvia: Donacidae) no estuário da Barra das Jangadas, Jaboatão, Pernambuco. Recife: Universidade Federal de Pernambuco. 198 p. Dissertação de Mestrado em Oceanografia Biológica.

DENADAI, MR., ARRUDA, EP., DOMANESCHI, O. and AMARAL, ACZ., 2006. Veneridae (Mollusca, Bivalvia) da costa norte do Estado de São Paulo, Brasil. Biota Neotropica, vol. 6 , no. 3, p.1-34.

FARIAS, MF. and ROCHA-BARREIRA, CA., 2007. Conchas de moluscos no artesanato cearense. Fortaleza: NAVE/LABOMARUFC. $156 \mathrm{p}$.

FEDER, HM., HENDEE, JC., HOLMES, P., MUELLER, GJ. and PAUL, AJ., 1979. Examination of a reproductive cycle of Protothaca staminea using histology, wet weight-dry weight ratios, and condition indices. Veliger, vol. 22, no. 2, p. 182-187.

GALTSOFF, PS., 1964. The American oyster Crassostrea virginica (Gmelin). U.S. Fish and Wildlife Service Fishery Bulletin, vol. 64 , p. $1-457$.

GARCÍA-DOMINGUEZ, F., GARCÍA-MELGAR, G. and GONZÁLEZ-RAMÍREZ, P., 1993. Ciclo reproductivo de la almeja roñosa, Chione californiensis (Broderip, 1835) in Bahía Magdalena, Baja California Sur, México. Ciencias Marinas, vol. 19, no. 1, p. 15-28.

GARCÍA-DOMINGUEZ, F., GARCÍA-GASCA, SA. and CASTRO-ORTIZ, JL., 1994. Spawning cycle of the red clam Megapitaria aurantiaca (Sowerby, 1831) (Veneridae) at Isla Espiritu Santo, Baja California Sur, Mexico. Journal of Shellfish Research, vol. 13, no. 2, p. 417-423.

GROTTA, M. and LUNETTA, JE., 1980. Ciclo sexual de Anomalocardia brasiliana (Gmelin, 1791) (Mollusca - Bivalvia) do litoral do Estado da Paraíba. Revista Nordestina de Biologia, vol. 3 , no. 1, p. 5-55.

GROTTA, M. and LUNETTA, JE., 1982. Reproductive physiological variation of Anomalocardia brasiliana (Gmelin, 1791) (MolluscaBivalvia), in different latitudes. Revista Nordestina de Biologia, vol. 5, no. 1, p. 21-28.

HELLER, J., 1993. Hermaphroditism in molluscs. Biological Journal of the Linnean Society, vol. 48, p. 19-42. http://dx.doi. org/10.1111/j.1095-8312.1993.tb00874.x

LEONEL, RMV., MAGALHÃES, ARM. and LUNETTA, JE., 1983. Sobrevivência de Anomalocardia brasiliana (Gmelin,1791) (Mollusca: Bivalvia), em diferentes salinidades. Boletim de Fisiologia Animal, Universidade de São Paulo, vol. 7, p. 63-72.

LOOSANOFF, VL., 1937. Development of the primary gonad and sexual phases in Venus mercenaria Linnaeus. Biological Bulletin, vol. 72, p. 389-405. http://dx.doi.org/10.2307/1537698

LOOSANOFF, VL. and DAVIS, HC., 1952. Temperature requirements for maturation of gonads of northern oysters. Biological Bulletin, vol. 103, p. 80-96. http://dx.doi.org/10.2307/1538408

LUBET, P., 1959. Recherches sur le cycle sexuel et l'emission des gamètes chez les Mytiloidae et les Pectinidae (mollusques bivalves). Revue des Travaux de l'Institut Scientifique des Pêches Maritimes, vol. 23, p. 387-548. 
-, 1996. Bases biológicas del cultivo de moluscos: Reproducción de los moluscos. In BARNABÉ, G. (Coord.). Bases biológicas y ecológicas de la acuicultura. Zaragoza: Editorial Acribia. p. 171-196.

LUNETTA, JE. and GROTTA, M., 1982. Influência de fatores exógenos e endógenos sobre a reprodução de moluscos marinhos. Boletim de Fisiologia Animal, São Paulo, vol. 6, p. 191-204.

MARTÍNEZ-CÓRDOVA, LR., 1988. Bioecología de al almeja negra Chione fluctifraga (Sowerby, 1853). Revista de Biología Tropical, vol. 36, no. 2A, p. 213-219.

MORTON, B., 1991. Do the Bivalvia demonstrate environmentspecific sexual strategies? A Hong Kong Model. Journal of Zoology, vol. 223, p. 131-142. http://dx.doi.org/10.1111/j.1469-7998.1991. tb04754.x

NARCHI, W., 1972. Comparative study of the funcional morphology of Anomalocardia brasiliana (Gmelin, 1791) and Tivela mactroides (Born, 1778) (Bivalvia, Veneridae). Bulletin of Marine Science, vol. 22 , no. 3, p. 643-670.

-, 1974. Aspectos ecológicos e adaptativos de alguns bivalves do litoral paulista. Papéis Avulsos de Zoologia, São Paulo, vol. 27, p. $235-262$.

-, 1976. Ciclo anual de gametogênese de Anomalocardia brasiliana (Gmelin, 1791) (Mollusca, Bivalvia). Boletim de Zoologia da Universidade de São Paulo, vol. 1, p. 331-350.
NASCIMENTO, IA. and LUNETTA, JE., 1978. Ciclo sexual da ostra de mangue e sua importância para o cultivo. Boletim de Zoologia da Universidade de São Paulo, vol. 2, p. 63-93.

PEZZUTO, PR. and ECHTERNACHT, AM., 1999. Avaliação de impactos da construção da via expressa SC-SUL sobre o berbigão Anomalocardia brasiliana (Gmelin, 1791) (Mollusca: Pelecypoda) na Reserva Extrativista Marinha do Pirajubaé (Florianópolis, SC-Brasil). Atlântica, vol. 21, p. 105-119.

PIZARRO, B. and CRUZ, F., 1987. Ciclo reproductivo de la almeja Protothaca grata (Pelecypoda: Veneridae). Brenesia, vol. 27, p. 23-34.

RIOS, EC., 2009. Compendium of Brazilian Sea shells. Rio Grande: Evangraf. 676 p.

ROCHA-BARREIRA, CA. and ARAÚJO, MLR., 2005. Ciclo reprodutivo de Anomalocardia brasiliana (Gmelin, 1791) (Mollusca, Bivalvia, Veneridae) na praia do Canto da Barra, Fortim, Ceará, Brasil. Boletim do Instituto de Pesca, vol. 31, no. 1, p. 9-20.

SASTRY, AN., 1979. Pelecypoda (excluding Ostreidade). In GIESE, AC. and PEARSE, JS. (Eds.). Reproduction of marine invertebrates. New York, Boston: Academic Press. p. 113-292. vol. 5 .

SHAW, BL. and BATTLE, HI., 1957. The gross and microscopic anatomy of the digestive tract of the oyster Crassostrea virginica (Gmelin). Canadian Journal of Zoology, vol. 35, p. 325-347. http://dx.doi.org/10.1139/z57-026 